NBER WORKING PAPER SERIES

DO PROFESSIONAL CURRENCY MANAGERS BEAT THE BENCHMARK?

\author{
Momtchil Pojarliev \\ Richard M. Levich \\ Working Paper 13714 \\ http://www.nber.org/papers/w13714
}

NATIONAL BUREAU OF ECONOMIC RESEARCH

1050 Massachusetts Avenue

Cambridge, MA 02138

December 2007

We acknowledge helpful comments from Mark Anson and Robert Whitelaw on earlier drafts of this paper. Any errors that remain are our own responsibility. The views expressed herein are those of the author(s) and do not necessarily reflect the views of the National Bureau of Economic Research.

(C) 2007 by Momtchil Pojarliev and Richard M. Levich. All rights reserved. Short sections of text, not to exceed two paragraphs, may be quoted without explicit permission provided that full credit, including $\odot$ notice, is given to the source. 
Do Professional Currency Managers Beat the Benchmark?

Momtchil Pojarliev and Richard M. Levich

NBER Working Paper No. 13714

December 2007

JEL No. F31

\begin{abstract}
$\underline{\text { ABSTRACT }}$
We investigate an index of returns on professionally managed currency funds and a subset of returns from 34 individual currency fund managers. Over the period 1990-2006, excess returns earned by currency fund managers have averaged 25 basis points per month. We examine the relationship of these returns to four factors representing returns based on carry trading, trend-following, value trading and currency volatility. These four factors explain a substantial portion of the variability in index returns in the entire period and in sub-periods. We perform similar regressions for the 34 individual funds, and find many funds where returns are significantly related to these four factors. Our approach impacts the definition of alpha returns from currency speculation, modifying it from the excess return earned by the fund, to only that portion of the excess returns not explained by the four factors. While the impact on measured alpha is substantial, we find that some currency fund managers continued to generate alpha returns in the most recent sample period.
\end{abstract}

Momtchil Pojarliev

Hermes Investment Management Limited

Lloyds Chambers, 1 Portsoken Street

London E1 8HZ England

m.pojarliev@hermes.co.uk

Richard M. Levich

Stern School of Business

New York University

44 West 4th Street

New York, NY 10012

and NBER

rlevich@stern.nyu.edu 


\section{Do Professional Currency Managers Beat the Benchmark?}

\section{Introduction}

Over the last twenty years, the notion of currency as an asset class has gained a wider following. Inspired, perhaps, by numerous studies reporting profitability in various types of currency trading strategies, investment consultants have promoted currency products as a potential source of alpha. ${ }^{1}$ Taking one measure, the number of funds in the Barclay Currency Trader Index (BCTI) has grown from 44 in 1993 to 106 in 2006 (see Exhibit 1). While returns on the BCTI (an equally-weighted composite of managed programs that trade in currency futures and forwards) were initially in the healthy double-digit range, those returns have tended to diminish over time, especially over the last few years.

If currency is indeed an asset class, we should be able to identify a set of factors that correlate with managers' realized returns from currency investment. In this paper, we measure the extent to which currency managers' returns correlate with four factors that are intended to represent feasible benchmark returns from distinct styles of currency

\footnotetext{
${ }^{1}$ Poole (1967), Dooley and Shafer (1984), Sweeney (1986), Levich and Thomas (1993), and Neely, Weller and Dittmar (1997), among others have documented the profitability of technical trend following models in currency markets. Bilson (1981) demonstrated that a persistent forward rate bias could be exploited for trading profits, and many others have shown the general tendency for currencies with high interest rates to appreciate. See Froot and Thaler (1990) for a survey and Burnside, et al. (2006) for a
} 
trading - carry, trend, value and volatility. Our results show that a substantial part of currency returns (both for the overall index and for 34 individual currency managers) can be explained by systematic exposure to these alternative trading strategies, i.e. style betas. We examine the stability of these relationships over time and find that both carry and trend played a significant role in the 1990s. However, the impact of the carry factor increased somewhat after 2000, while the impact of the trend factor declined. Nevertheless, the trend factor remained the most dominant factor in terms of R-squared. It explains more than $65 \%$ in the variability of the excess currency returns in the $1990 \mathrm{~s}$ and after 2000 . In the 1990 s, currency manager returns were, at the margin, significantly negatively related to the value factor, meaning that currency managers as a group tended to bet against Purchasing Power Parity and were the worse off for it. After 2000, currency manager returns are positively and significantly related to the volatility factor. Post-2000, nearly $77 \%$ of the variability in monthly returns on the BCTI can be explained by our four factors.

The results for individual managers are naturally more diverse than for the overall index. In the six-year period ending in 2006 , we find that 8 of 34 currency fund managers produced excess returns (over and above the returns associated with the four factors) that are statistically significant and average about 104 bps per month. While overall managed currency returns have declined sharply over the last 20 years, some individual managers appear still capable of generating alpha compared to our four factor benchmarks.

recent study. Studies prepared at Citibank (2003) and Deutsche Bank (2007) suggest that simple trading strategies based on mean reversion to long run PPP exchange rates have been profitable. 
Our approach significantly alters the definition and measurement of alpha returns in the context of currency speculation. For various reasons (e.g. currency returns alleged to be unpredictable or uncorrelated with equity benchmarks), most studies have adopted zero for currency overlay programs and the risk-free return for absolute return programs as the appropriate return benchmarks for currency speculation. ${ }^{2}$ In prior studies, all excess returns were classified as alpha return, i.e. beta returns were assumed away. In our framework, alpha currency returns are those over and above returns associated with transparent and readily implemented currency trading strategies. As exchange traded funds become available to proxy the returns from basic currency trading strategies, investors can capture these returns (i.e. beta returns) with minimal cost. In our framework, professional currency managers who simply mimic the strategies embodied in our four factors are unlikely to earn alpha. Our empirical results support this, showing a significant inverse relationship between alpha returns and the variation explained by the four factors.

\footnotetext{
${ }^{2}$ A currency overlay program is simply a mandate for trading on the basis of assets invested elsewhere. If the overlay manager does nothing, he earns zero return. An absolute return program manager holds assets under management which if left unmanaged earn the risk-free rate.
} 


\section{Explaining Currency Index Returns}

Until recently, it was nearly unthinkable to propose modelling speculative currency returns in anything like the framework applied in equity markets. A few stylized macroeconomic models developed conditions under which a forward currency risk premium could exist. ${ }^{3}$ Despite this, a prominent theme in academic studies is that currency returns are not forecastable and so expected returns are zero. ${ }^{4}$ However, other studies have documented that various currency trading strategies have been profitable, and also that these returns are weakly correlated with other asset classes (e.g. equities, bonds, and real estate) making currency desirable as a "zero beta" asset for traditional institutional investors. $^{5}$

While currency trading returns may be unrelated to equity market returns, they may be related to other factors. In a recent paper, Anson (2007) argues that there is a continuum between beta and alpha. In Anson's view, there exist different types of beta, ranging from the classic beta, which we know from the CAPM model, to other betas, which reflect systematic exposure to other defined facets of the market. What could pass for "alpha" might simply be systematic exposure to some other style factor.

Even so, currency investing does not neatly fit into equity market paradigms. The currency market is a long-short market, where going long one currency by necessity

\footnotetext{
${ }^{3}$ See Branson and Henderson (1985) for a survey article.

${ }^{4}$ Meese and Rogoff (1983) is the seminal article in this area. Rogoff (2002) argues that the evidence for unpredictability is still compelling.

${ }^{5}$ See the studies cited in footnote 1. Burnside, et al. (2006), among others, shows that currency returns are uncorrelated with other asset classes.
} 
means going short in another currency. A currency investor might borrow 1 million GBP to finance an investment in 2 million USD. In principle, currency investing requires no net investment and there is no natural "market portfolio" to track, making the concept of beta seem inappropriate for currencies.

With the realization that there are different types of beta and returns may be systematically related to well-defined factors, the concept of currency betas gains logic. Recently, both Citibank and Deutsche Bank have introduced currency benchmark indices to track the performance of currency returns building on several well defined components. ${ }^{6}$ We follow on this approach by analyzing four potential factors that could explain currency returns earned by professional managers. Once specified, we can then estimate what portion of currency trading profits is due to exposure to these specific trading style or risk factors, and what portion is due to skill, or alpha.

\section{Currency Returns, Factors and Methodology}

To measure the systematic components of currency returns (the betas) and isolate the portion due to skill, we use a standard factor model of the form:

$$
R_{t}=\alpha+\sum_{i} \beta_{i} F_{i, t}+\varepsilon_{t}
$$

where

\footnotetext{
${ }^{6}$ The Citibank (2007) Betal Index is constructed from the returns on four trading styles: a trend component, a G10 carry component, an emerging market carry component, and a Purchasing Power Parity component. The Betal indices are calculated for Citibank by Deutsche-Borse and available through Bloomberg. The Deutsche Bank Currency Returns Index, described in Hafeez (2007) is a combination of three trading styles: trend, carry and value (given by PPP). Both Citibank and Deutsche Bank specify welldefined strategies for each component, however there are differences in the details of each.
} 
$R$ is the excess return generated by the currency manager, defined as the total return $\left(R_{t}^{*}\right)$ less the periodic risk-free rate $\left(R_{F, t}\right)$

$\alpha$ is a measure of active manager skill,

$F$ is a beta factor, that requires a systematic risk premium in the market,

$\beta$ is a coefficient or factor loading that measures the sensitivity of the manager's returns to the factor, and

$\varepsilon$ is a random error term.

We consider four factors that proxy for types of trading strategies and exposures that currency managers would be likely to utilize.

Carry Factor. The so-called carry trade is a well-known strategy employed by currency managers. In a carry trade, the manager borrows the low interest rate currency (e.g. Japanese yen) and invests in a high interest rate currency (e.g. New Zealand dollar). The risk is that the high interest rate currency may depreciate, and possibly by more than the interest differential which would result in a loss. As a proxy for the carry factor, we use Citibank's Beta1 G10 Carry Index which takes a long position in high yielding

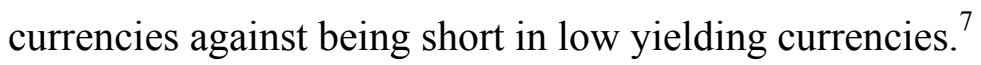

Trend-Following Factor. Many currency managers rely on trend-following strategies in one or more of their many variations. There are many risks inherent in trend-following such as sudden reversals of trends or patterns, trading based on false signals, excessive trading costs, and so on. As a proxy for the trend-following factor, we

\footnotetext{
${ }^{7}$ The Citibank Beta1 G10 Carry Index represents an equally weighted basket of carry trades within 13 pairs of currencies selected from among the ten major currencies.
} 
use the AFX Currency Management Index. ${ }^{8}$ The AFX Index is based on earlier research by Lequeux and Acar (1998) which showed that an equally-weighted portfolio of three moving average rules (32, 61 and 117 days) was a good proxy for a trend-following style among professional managers.

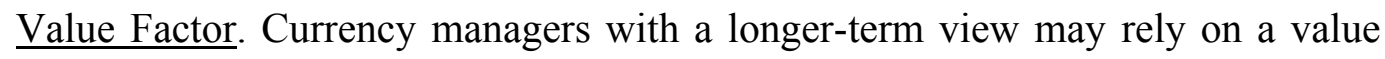
benchmark to gauge when currencies are over or under valued. Purchasing Power Parity (PPP) in one of its many variants is a commonly used benchmark to represent a long-run equilibrium value. Empirical evidence suggests that currencies often overshoot their PPP values in the short run, and show a tendency to revert back toward PPP in the longer run. ${ }^{9}$ One trading strategy is then to identify currencies that are substantially misaligned with the expectation that they will move closer to PPP over time. The risks in this strategy include the possibility that currency values may become still more misaligned, that rates will be slow to revert toward PPP, or that the currency's long-run real exchange rate has changed consistent with a new PPP exchange rate. As a proxy for the value factor, we use Citibank's Beta1 G10 Purchasing Power Parity Index which takes a long position in currencies that are more than $20 \%$ undervalued against short positions in currencies that are more than $20 \%$ overvalued. ${ }^{10}$

Volatility Factor. Yet another style of professional currency investment involves trading on currency volatility. Currency managers gain exposure to volatility risk simply by taking open currency positions, but also by using options and other derivatives whose

\footnotetext{
${ }^{8}$ The AFX Index is based on trading in seven currency pairs EUR-USD, USD-JPY, USD-CHF, GBPUSD, EUR-JPY, EUR-GBP, EUR-CHF weighted by their volume of turnover in the spot market. The AFX Index is prepared at Liverpool John Moores University.

${ }^{9}$ Recent evidence on PPP is reviewed in Taylor and Taylor (2004).
} 
prices are sensitive to volatility. Managers are at risk if they are long (short) volatility when volatility declines (increases). As a proxy for currency volatility, we use the average of the 1-month implied volatility for the EUR-USD exchange rate and for the USD-JPY exchange rate. These two currency pairs have the most liquid options in the foreign exchange market, accounting for roughly $54 \%$ of currency option trading in the BIS surveys from 1995-2004. ${ }^{11}$

\section{Empirical Results - Currency Index Returns}

To investigate the relationship between currency trader returns and our four factors, we collected monthly data on the BCTI for the period January 1990 until December 2006 (204 months). ${ }^{12}$ All funds represented in the BCTI are absolute return programs. We use the 1-month USD LIBID rate to proxy the risk-free return on the assets under management in these programs. ${ }^{13}$ Simple descriptive statistics on these variables for the entire sample and for two sub-periods are presented in Exhibit 2.

\footnotetext{
${ }^{10}$ The Citibank Beta1 G10 PPP Index relies on 13 pairs of currencies selected from among the ten major currencies and uses OECD measures of Purchasing Power Parity.

${ }^{11}$ Prior to the introduction of the Euro in January 1998, we use implied volatility for DEM-USD rate.

${ }^{12}$ We are grateful to the Barclay Group for supplying the monthly data on their index.

${ }^{13}$ We use the 1-month USD LIBOR rate on the last day of month $t-1$ as quoted by the British Bankers Association less $12.5 \mathrm{bps}$ as our proxy for LIBID in month $t$.
} 
The mean monthly return on the Barclay Currency Trader Index is $0.62 \%$, or roughly $7.5 \%$ per annum over the 17 -year period. The excess return on the BCTI is then the monthly minus the 1-month USD LIBID rate. As a result, the mean monthly excess return on the BCTI is only $0.25 \%$, similar to the returns on the G10 Carry Index and the AFX Index, which averaged $0.15 \%$ and $0.21 \%$ per month respectively. Returns on the G10 PPP Index were far smaller, only $0.03 \%$ per month. As expected, the carry factor exhibits negative skewness and the trend factor positive skewness. While trendfollowing is a long volatility strategy, carry trading is a short volatility strategy. The value factor also shows slight negative skewness and positive kurtosis. Kurtosis for the BCTI is more pronounced than for any of the four factors. The volatility factor (representing percentage implied volatility rather than a return) has a negative mean indicating that volatility was, on average, declining over the sample period. ${ }^{14}$

In the two sub-periods, mean excess returns on the Barclay Index were far higher, $0.36 \%$ per month, in the first period versus only $0.08 \%$ per month in the second period. Likewise, kurtosis in the BCTI was far lower in the second period compared to the first. Mean monthly returns on two of our factors, trend and volatility, were substantially lower in the second period $(0.05 \%$ and $-0.08 \%$ respectively) as compared to the first period $(0.31 \%$ and $0.02 \%)$. On the other hand, mean monthly returns on the carry and value factors were higher in the second period $(0.21 \%$ and $0.06 \%$ respectively) as compared to the first period $(0.13 \%$ and $0.02 \%)$.

${ }^{14}$ There is substantial correlation between our currency volatility measure and the VIX index (a proxy for the volatility in the equity market) and the MOVE index (a proxy for the volatility in the bond market). All 


\section{Currency Index Returns and Explanatory Factors.}

To examine the relationship between the overall currency returns and explanatory factors, we regress the excess monthly returns on the Barclay Currency Traders Index against all possible combinations of our four factors. We report the results for the most relevant combinations.

The results for the full sample period are shown in Exhibit 3. First, the R-square for the regression is relatively high, indicating that these factors (carry, trend, value and volatility) account for roughly $66 \%$ of the variability in monthly excess returns over the entire sample period. $^{15}$

Trend appears to be the most significant factor. The trend coefficient exceeds one and is highly significant in each of the specifications which use trend as an explanatory variable. On average, the managers in the Barclay Index demonstrate an amplified movement relative to the trend factor. The trend factor alone explains almost $65 \%$ of the variability of the excess returns of the BCTI (see specification 4 in Exhibit 3). The carry coefficient is also positive and significant. In specification 1 , the value coefficient is significant but negative, suggesting that managers in the BCTI held positions favoring a continuation of trend rather than mean reversion. In specifications 3 that omits the value

three measures have declined considerably since 2000 .

${ }^{15}$ To test for the possibility that monthly returns are managed, we included one-month lagged returns as a fifth explanatory variable. This variable was not statistically significant. 
factor, the carry coefficient drops substantially. This is consistent with the fact that the carry and value factors are highly correlated (roughly 0.65 ) in our sample.

The volatility coefficient is not significant in specification 1 for the full sample, but it is significant on a stand alone bases. The positive volatility coefficient may be suggesting that excess returns are higher in periods of rising volatility. According to surveys by the Bank of International Settlement (BIS), turnover in foreign exchange options expanded five-fold between 1995 and 2007, and the ratio of the turnover in currency options to the turnover in currency forwards has more than tripled between the 2001 and 2007 surveys. Volatility, as we will show, could play a larger role in more recent years.

Finally, the intercept term in specification 1 is $-0.09 \%$ and not statistically significant. This result implies that managers included in the BCTI were not able to generate alpha returns. After accounting for our four systematic risk factors - carry, trend, value and volatility - the first three of which reflect returns on naïve currency trading strategies, alpha was -9 bps per month or about $-1.1 \%$ per year over the 204 month period. So while the overall excess return on the BCTI was 25 bps per month (Exhibit 2), all of that return and more (34 bps) can be attributed to the four explanatory factors. ${ }^{16}$

To test for stability of these relationships over time, we divided the sample into two subperiods, January 1990 to December 2000 and January 2001 to December 2006. The

\footnotetext{
${ }^{16}$ Based on our estimated model, the 34 bps comprises 10 bps attributed to carry (equal to the carry coefficient multiplied by the average carry return), $27 \mathrm{bps}$ to trend, $-3 \mathrm{bps}$ to value and $0 \mathrm{bps}$ to volatility.
} 
regressions results for these two sub-periods are shown in Exhibit 4. Our discussion will focus primarily on specification 1 that includes all four factors.

The coefficient of the trend factor is significant in both sub-periods, but substantially higher in the 1990s than after 2000. In the first sub-period, 45 bps of monthly beta returns could be contributed to the trend factor, compared with only 4 bps after 2000 . The coefficient of the carry factor, which is 0.75 in the first period, increases to 1.04 in the second period, and is highly significant in both periods. In the first sub-period, 10 bps of monthly beta returns could be contributed to the carry factor, compared with 22 bps after 2000. These results imply that, on average, managers included in the BCTI increased their exposure to the carry factor and reduced their exposure to the trend factor in the post-2000 period. This is consistent with other evidence that returns to simple currency trend-following strategies declined in the late 1990s and beyond, leading currency managers to shift away from trend-following rules. ${ }^{17}$ Note that carry was not significant on a stand alone basis (specification 3) in the 1990s, but it is highly significant after 2000.

${ }^{17}$ See Pukthuanthong, Levich and Thomas (2007). 
The coefficient on the value factor is negative and significant in the first period, but the coefficient is smaller and insignificant in the second period. The coefficient on the volatility factor, which is small $(-0.05)$ and insignificant in the first sub-period, is substantially larger (0.33) and significant in the second sub-period. This result is consistent with the fact that trading in currency derivatives increased sharply after 2001, a point raised earlier. Similarly, it is interesting that -3 bps of beta returns could be contributed to volatility factor after 2000 ( 0.33 multiplied by average volatility $-0.08 \%)$. Volatility has been declining after 2000 (Exhibit 2), and our analysis suggests that declining volatility has reduced the excess returns earned by currency managers.

The intercept term, our indicator of alpha after accounting for other systematic risk factors, is -16 bps in the first sub-period. In the second period, the intercept term is -11 bps. Thus in both sub-periods, most of the variability in returns on the BCTI can be attributed to our four explanatory factors, with nothing attributed (on average) to excess performance or alpha.

Interestingly, despite the talk that recent years have been more challenging for active currency management, our analysis shows that that the average alpha return (as defined in equation 1) has been negative not only after 2000, but also in the 1990s. The average alpha is even "higher" after 2000 (-11 bps per month) than in the 1990s (-16 bps per month). As Exhibit 2 demonstrates, after 2000 we have witnessed a substantial decline in the returns generated by the trend strategy. Thus, in the post- 2000 period, beta returns have declined substantially, while alpha returns have remained similar. 


\section{Empirical Results - Individual Currency Manager Returns}

In addition to the performance of the overall BCTI, we also obtained data on the monthly performance of all 113 currency managers that make up the index as of the beginning of 2007. ${ }^{18}$ As shown in Exhibit 1, the number of currency managers covered in the BCTI has grown from 44 in 1993 to 113 in 2006. In this section, we examine the performance of those 34 currency managers included in the BCTI with a track record that spans a six-year period, January 2001 - December 2006.

Annualized returns, excess returns and standard deviation of excess returns for the 34 managers are shown in Exhibit 5. We also report the annualized alpha return and the standard deviation of alpha returns (tracking error). The average excess annual return for all 34 managers is positive, ranging from $0.80 \%$ to $22.98 \%$. This broad range of outcomes highlights a well-known aspect of currency management. There is a lack of standardized mandates and risk/return profiles vary substantially across different clients. Therefore it is very difficult to compare one currency manager with another.

The traditional way of computing IR for currency managers is to assume that the excess returns equal alpha returns (beta returns are zero). The information ratio (IR) is then simply the annualized excess return divided by the annualized standard deviation of the excess returns. Our results in Exhibit 5 show that these 34 currency managers have been performing well since 2001 - their average IR is 0.47 . The IRs range from -1.99 to 1.67

\footnotetext{
${ }^{18}$ We are grateful to the Barclay Group for supplying the monthly data on individual managers who are identified only by number and not by name.
} 
with a median value of 0.45 . These results probably overstate the performance that could be expected from currency management due to survivorship bias. ${ }^{19}$ As important, however, the results based on IR may be misleading as the calculation assumes that the risk-free return is the appropriate benchmark for returns.

In our framework as presented in equation (1), alpha returns $\alpha_{\mathrm{j}}$ for fund manager $j$ would be only that portion of excess returns that are not explained by the four factors, or

$$
\hat{\alpha}_{j}=R_{j, t}-\sum_{i} \hat{\beta}_{i, j} F_{i, t}+\varepsilon_{j, t}
$$

We can thus define an alternative information ratio $I R_{j}^{*}=\alpha_{j} / \sigma\left(\alpha_{j}\right)$ that reflects alpha returns divided by their standard deviation or tracking error. Calculations shown in Table 6 show that the mean and median values of IR ${ }^{*}$ are smaller than the traditional IR. There is a substantial impact on the ranking of funds. For example, several funds (M2, M5, M6, M17, M21 and M22) show a substantial decline using IR ${ }^{*}$ compared with IR. These six managers switch from positive IR values to negative $\mathrm{IR}^{*}$ values. On the other hand, several funds (M7, M8, and M32) show a marked increase using $\mathrm{IR}^{*}$ rather than the traditional IR. This large impact follows from the fact the some funds are earning beta returns while other funds are offering pure alpha returns in the sense of equation (2).

\footnotetext{
${ }^{19}$ As one indicator of the potential bias, in 2001, the BCTI was based on data from 47 funds. Only 34 of those survived to establish a full six-year history through 2006.
} 
To investigate how much of these returns is pure alpha and how much is due to exposure to risk factors (beta), we regress the monthly excess returns of the 34 currency managers against the four explanatory factors. Exhibit 6 summarizes our results.

Several observations stand out. First, only 8 managers exhibit positive and significant alpha (intercept). This shows that the IRs from Exhibit 5 might be misleading as a substantial part from the returns stems from exposure to our trading factors. In the context of our factor model (equation 1), returns generated by currency managers are not pure alpha returns, but consist of alpha and beta returns. For example, manager M2 has significant exposure towards three factors - carry, trend, and volatility. The coefficients on these three factors are highly significant and the R-square (0.688) is the highest of all 34 managers. This manager has generated an annualized excess return of $3.70 \%$ since 2001 (see Exhibit 5), but these appear to be primarily beta returns. The alpha for M2 is negative (2 bps per month) and not statistically different than zero. As highlighted by Exhibit 5 the annualized alpha return is $-2.48 \%$, leading to a poor IR* of -0.52 .

On the other end of the spectrum is manager M28. The R-square for M28 is 0.0347 , among the lowest in our sample, suggesting that he has no significant exposure towards any of our four factors. However, manager M28 has generated a significant alpha of $0.29 \%$ per month. The average annualized excess return for manager M28 is $3.02 \%$, a little less than the excess return generated by manager M2 (3.70\%). However, our analysis shows that M28 is offering alpha returns while M2 is offering beta exposure. Therefore, the IR ${ }^{*}$ for M28 is higher than his standard IR (0.93 instead of 0.78$)$ while the 
$I^{*}$ for M2 turns negative and is much lower than his standard IR ( -0.52 instead of 0.74$)$. The IR*s of these two managers are completely different (which might lead to different incentive fees), while the IRs are almost identical, 0.74 for M2 and 0.78 for M28.

In Exhibit 6, R-square exceeds 50\% for 9 of the 34 managers. This seems remarkable as the currency managers in our sample are not restricted to developed markets, but our model uses only factors for developed market currencies. These results are potentially very important as they could have implications on pricing investment mandates. Clients may be willing to pay high fees for alpha, but beta exposure should be gained more cheaply.

Second, the highest exposure remains towards the trend-following factor. The trend factor is significant for 15 managers. The carry factor is significant for 8 managers and volatility and value are significant for only 7 and 5 managers, respectively. This suggests that the trend style continues to dominate among currency managers; however, the other factors appear to play a significant role for some funds.

Several managers (M7, M8 and M14 for example) have negative exposure towards carry. ${ }^{20}$ These could be value managers as currencies which are presumed to be undervalued often exhibit low interest rates (like the Swiss franc and the Japanese yen). One manager (M4) has a negative exposure towards the trend factor and might be characterized as "contrarian." 
Twenty-one of the 34 managers have a significant exposure to at least one factor, 9 of those have a significant exposure to two factors, and 2 funds have a significant exposure to three factors. Manager M30 has a significant exposure to all four factors. This implies that managers have been diversifying across different styles by having exposure towards more than one style factor. ${ }^{21}$ On the other hand, 13 of the 34 managers have no significant exposure towards any style factor. For these 13 managers, none of the coefficient t-statistics are significant at $95 \%$ confidence level. These managers might be classified as the true alpha chasers or they simply might be offering exposure to other trading styles or risk factors than the four considered here. ${ }^{22}$

\section{Sources of Alpha - The Role of Timing}

In principle, currency managers might earn alpha returns from a variety of skilful trading decisions including which currencies to pair in a trading strategy, how to weight those positions in the overall portfolio, which instruments to use to establish their positions, and when to enter and lift their trades. We wish to investigate whether managers demonstrate any timing expertise in the sense of shifting their reliance on a particular trading style as returns from that style vary. A manager with the expertise to increase (decrease) his reliance on factor $F_{i}$ when returns on $F_{i}$ are rising (falling) shows positive

\footnotetext{
${ }^{20}$ In a specification that omits the value factor, these coefficients are also statistically significant.

${ }^{21}$ Using simulated data, Binny (2005) shows that alternative currency trading styles (value forecasting, trend following, return forecasting and non-directional strategies) produces returns that were imperfectly correlated.

${ }^{22}$ We again included lagged returns as a fifth explanatory variable. Lagged returns were significant for 6 managers with significant positive coefficients in 4 cases and significant negative coefficients in 2 cases.
} 
timing ability. To test this possibility, we run regressions of the following form for each manager:

$$
R_{j, t}=\alpha_{j}+\sum_{i} \beta_{i, j} F_{i, t}+\sum_{i} \gamma_{i, j} F_{i, t}^{2}+\mu_{j, t}
$$

Our results in Exhibit 7 show 19 significant coefficients (or 14\% of the 4 squared terms in the 34 regressions) on the quadratic terms ( 3 for carry timing, 7 for trend timing, 3 for value timing and 6 for volatility timing). Fully 17 of these coefficients are positive indicating market timing ability. About one-half of the managers have market timing ability in some style, with the greatest timing ability in the trend factor.

Note also that the intercepts in the market timing regressions are smaller than in the four factor regression. Only 2 managers (M8 and M29) have positive and significant intercept terms after accounting for market timing compared with 8 in the four factor model. This suggests that much the alpha returns come from market timing.

\section{Alpha Returns and Beta Returns - A Possible Trade-Off}

To investigate the potential trade-off between true alpha and style betas as hypothesized by Anson (2007), we regress the intercept terms (alphas) for each of the 34 funds against the $\mathrm{R}^{2}$ from the time series regression of each fund. The results of this cross-sectional regression are shown in Exhibit 8. We find a significant inverse relationship such that

These results are consistent with the notion that returns at some funds may be managed. In two cases (M16 and M23), alpha became insignificant after adding lagged returns to the regression. 
each $1 \%$ increase in $\mathrm{R}^{2}$ tends to reduce monthly excess returns by about 1.4 basis points. The more that individual fund returns can be explained by our four style factors, the less likely is the fund to generate a true alpha in the sense of a return that is uncorrelated to a readily attained market index or trading strategy.

\section{Grouping Managers into a Fund of Funds}

As one final experiment, we consider a new portfolio, a "fund of funds" comprised of equally weighted positions in each of the 34 funds over the 2001-2006 period. The results in Exhibit 6 show that this particular fund of funds earned alpha returns of $31 \mathrm{bps}$ per month, which is precisely the same as the simple average alpha of all 34 funds in our sample. Note, however, that the t-statistic on alpha for the fund of funds is 2.92 and highly significant, while the average t-statistic for alpha across all 34 funds is only 0.74 . This result captures the diversification effect of investing in 34 funds versus the expected or average result from investing in a single currency manager. The returns on our naïve, evenly weighted fund of funds are significantly related to three factors (carry, trend and volatility), which explain $73 \%$ of the variation in those returns. Yet there is a highly significant alpha for the fund of funds.

Importantly, the superior performance of the fund of funds could in part reflect survivorship bias. As noted earlier, in 2001 there were 47 funds in the BCTI. A naïve fund of funds on all 47 funds would have realized different, and probably lower, returns than our fund of funds based only on survivors. We are not able to quantify this effect because of data limitations. 


\section{Conclusions}

In this paper, we have investigated which factors help to explain an index of currency trader returns and the returns for individual currency managers. The results show that four factors, representing four styles of currency investing, explain a significant part of these returns. The average excess return of the BCTI index was positive at 25 bps per month between 1990 and 2006. However, once we account for the four systematic beta factors, the alpha is negative at -9 bps per month and not statistically different from zero. This is not encouraging news for currency managers.

There are some interesting differences between the 1990s and the post-2000 period. First, volatility is not a significant factor in the 1990s, but it is significant after 2000. This may be related to the increase in options turnover in the most recent years. Second, the average excess return in the 1990s was 36 bps per month, but after 2000 the average excess return has declined to only 8 bps per month. However, in both periods currency managers were not able to generate a positive alpha on average. Despite all the talk that the recent years have been more challenging for currency management, we have witnessed a decline only in the beta returns. The average alpha has remained almost the same: -16 bps per month in the 1990 and -11 bps per month after 2000.

However, not all is bad news for currency managers. Our results show that $24 \%$ of the managers were able to generate positive and significant alpha between 2001 and 2006 . The average alpha of these "stars" has been quite high at 104 bps per month or $12.48 \%$ per year and significant. Importantly, this 104 bps alpha is measured after taking into 
account the four explanatory factors - carry, trend, value and volatility - the first three of which reflects returns on naïve currency trading strategies. This demonstrates that currencies have similarities with other asset classes whose returns can be related to risk factors. Although, the average manager might underperform, there exist some skilled managers who are able to deliver significant alpha.

What do our results mean for active currency management? Our results support the notion that the foreign exchange market offers opportunity for alpha generation. However, greater emphasis should be put on "active" in currency management. Our factor model makes clear that all returns generated by currency managers are not pure alpha. A significant part of currency returns comes from exposure to a small set of factors that proxy the returns from well-known and easily implemented trading styles. This realisation may lead to some re-pricing for "active" currency products. It will be difficult to justify a $2 \%$ management fee and $20 \%$ performance fee for exposure to currency style betas when exposure to equity style betas might be gained for 3 to $10 \mathrm{bps}$.

Our results suggest that the recent lacklustre returns from currency managers are the result of declining beta returns stemming mainly from the declining profitability of trend-following rules and not the result of declining alpha generation. In the context of our factor model, alpha generation has not declined after 2000 in comparison to the 1990s. Our results show that delivering alpha has never been an easy task. This explains why investors might be willing to pay high fees for true alpha performance. An index of currency managers tended to underperform in the 1990s and post 2000. However, some 
skilful managers have been able to deliver positive and significant alphas. 


\section{References}

Anson, M. "The Beta Continuum: Classic Beta, Bespoke Beta, Alternative Beta, Fundamental Beta, Cheap Beta, and Active Beta", Journal of Portfolio Management, 2007. (forthcoming)

Bilson, J. F. O. “The 'Speculative Efficiency' Hypothesis,” Journal of Business, July 1981, pp. 435-451.

Binny, J. "Currency Management Through the Ages," Journal of Alternative Investments, Winter 2005, pp. 52-59.

Branson, W. and D. Henderson, "The Specification and Influence of Asset Markets," in P. Kenen and R. Jones, eds., Handbook of International Economics, North-Holland, 1985.

Burnside, C., M. Eichenbaum, I. Kleschelski, and S. Rebelo, "The Returns to Currency Speculation," NBER working paper 12916, August 2006.

Citibank, CitiFX Risk Advisory Group, "Investor Strategy: A Fresh Look at Purchasing Power Parity," August 2003.

Citibank, CitiFX Risk Advisory Group, "The Beta1 Index: A Benchmark for active FX Returns," 2007.

Deutsche Bank, "Currencies: Value Investing," March 29, 2007.

Dooley, M. P., and J. R. Shafer. "Analysis of Short-Run Exchange Rate Behaviour: March 1973 to September 1975." Federal Reserve Board, International Finance Discussion Paper, No. 123, (1976).

Froot, K. and R. Thaler, "Anomalies: Foreign Exchange," Journal of Economic Perspectives, Summer 1990, pp. 179-92.

Hafeez, B. "Benchmarking Currencies: The Deutsche Bank Currency Returns (DBCR) Index, DB Global Market Research, March 29, 2007.

Lequeux, P., and E. Acar. "A Dynamic Benchmark for Managed Currencies Funds" European Journal of Finance, 4 (1998), pp. 311-330.

Levich, R. M., and L. R. Thomas, III. "The Significance of Technical Trading-Rule Profits in the Foreign Exchange Market: A Bootstrap Approach." Journal of International Money and Finance, 12 (1993), pp. 451-474. 
Neely, C. J., P. Weller, and R. Dittmar. "Is Technical Analysis in the Foreign Exchange Market Profitable? A Genetic Programming Approach." Journal of Financial and Quantitative Analysis, 32 (1997), pp. 405-426.

Pojarliev, M. "Trading the Forward Rate Puzzle", Hermes Investment Management, Working Paper, 2007.

Poole, W. "Speculative Prices as Random Walks: An Analysis of Ten Time Series of Flexible Exchange Rates.” Southern Economic Journal, 33 (1967), pp. 468-478.

Pukthuanthong, K. and R. Levich and L. Thomas, "Do Foreign Exchange Markets Still Trend?" Journal of Portfolio Management, Fall 2007. (forthcoming)

Rogoff, K. "The failure of empirical exchange rate models: no longer new, but still true," Economic Policy, web essay, posted at http://www.economicpolicy.org/pdfs/responses/Kenneth-Rogoff.pdf, 2002.

Sweeney, R. J. "Beating the Foreign Exchange Market." Journal of Finance, 41(1986), pp. 163-182.

Taylor, A. and M. Taylor, "The Purchasing Power Parity Debate," Journal of Economic Perspectives, Fall 2004, Vol. 18, No. 4, pp. 135-58. 


\section{Exhibit 1: Barclay Currency Traders Index, Annual Returns and No. of Funds}

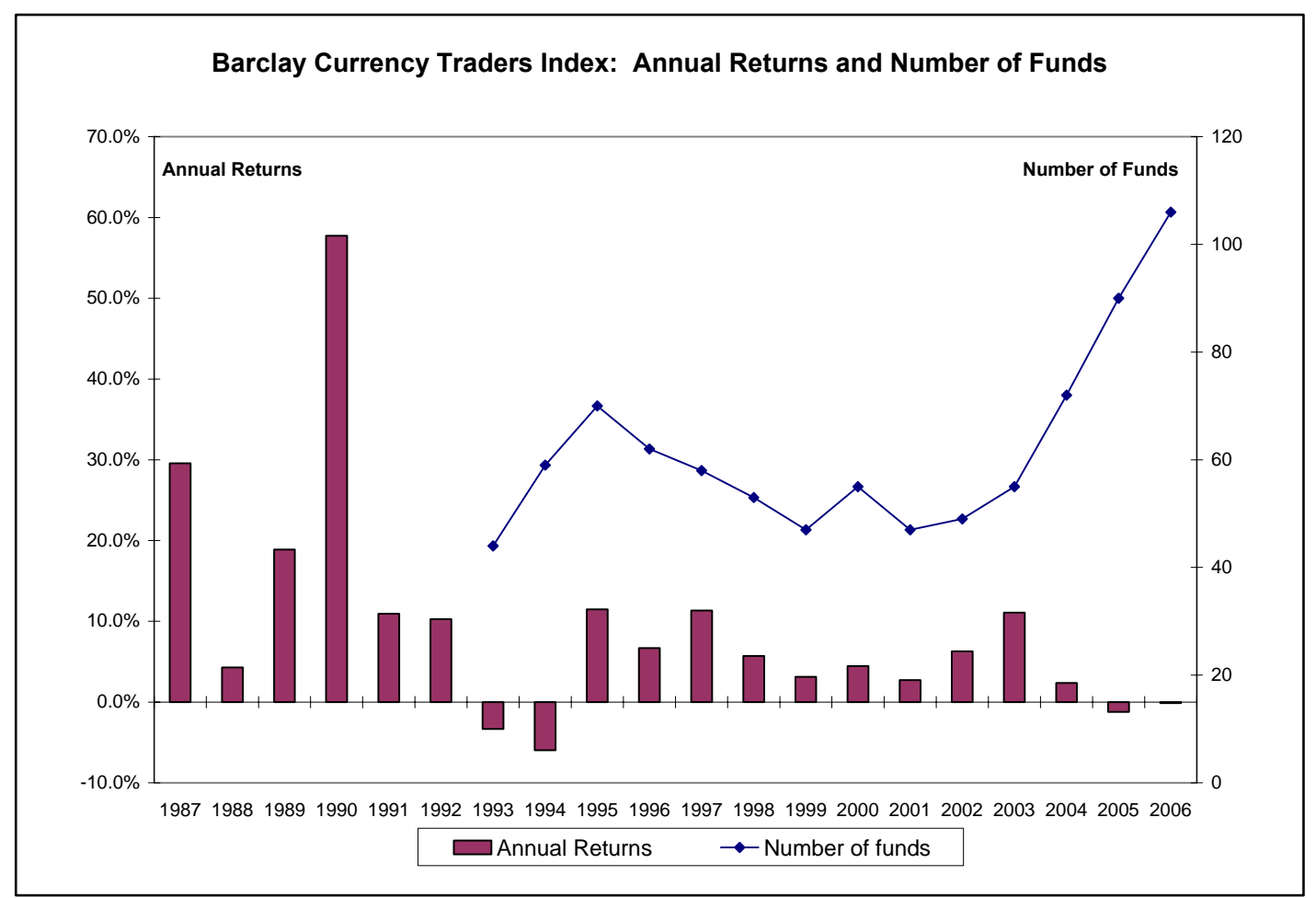

Source: The Barclay Group. Annual returns available at www.barclaygrp.com. Monthly returns and numbers of funds provided courtesy of the Barclay Group. 
Exhibit 2: Currency Returns and Currency Risk Factors, Descriptive Statistics

\begin{tabular}{|c|c|c|c|c|c|c|c|}
\hline & $\begin{array}{l}\text { Currency } \\
\text { Returns }\end{array}$ & $\begin{array}{c}\text { Risk-free } \\
\text { Returns }\end{array}$ & $\begin{array}{l}\text { Excess } \\
\text { Returns }\end{array}$ & $\begin{array}{l}\text { Carry } \\
\text { Factor }\end{array}$ & $\begin{array}{l}\text { Trend } \\
\text { Factor }\end{array}$ & $\begin{array}{l}\text { Value } \\
\text { Factor }\end{array}$ & $\begin{array}{l}\text { Volatility } \\
\text { Factor }\end{array}$ \\
\hline & $\begin{array}{c}\text { Barclay } \\
\text { Currency } \\
\text { Traders } \\
\text { Index }\end{array}$ & $\begin{array}{l}\text { USD } \\
\text { LIBID }\end{array}$ & $\begin{array}{l}\text { BCTI } \\
\text { minus } \\
\text { LIBID }\end{array}$ & $\begin{array}{l}\text { Beta1 } \\
\text { G10 } \\
\text { Carry } \\
\text { Index }\end{array}$ & $\begin{array}{l}\text { AFX } \\
\text { Index }\end{array}$ & $\begin{array}{l}\text { Beta1 } \\
\text { G10 PPP } \\
\text { Index }\end{array}$ & $\begin{array}{c}\text { FX } \\
\text { Volatility } \\
\text { Index }\end{array}$ \\
\hline \multicolumn{8}{|l|}{$\begin{array}{l}\text { Panel A. Jan. 1990 - } \\
\text { Dec. } 2006(\mathrm{~N}=204)\end{array}$} \\
\hline Mean monthly change & $0.62 \%$ & $0.37 \%$ & $0.25 \%$ & $0.15 \%$ & $0.21 \%$ & $0.03 \%$ & $-0.01 \%$ \\
\hline Standard Deviation & $3.06 \%$ & $0.16 \%$ & $3.04 \%$ & $0.78 \%$ & $1.86 \%$ & $0.38 \%$ & $1.55 \%$ \\
\hline Skewness & 1.60 & -0.17 & 1.54 & -1.05 & 0.84 & -0.43 & 0.84 \\
\hline Kurtosis & 4.76 & -0.60 & 4.54 & 2.86 & 1.61 & 3.30 & 3.42 \\
\hline \multicolumn{8}{|l|}{$\begin{array}{l}\text { Panel B. Jan. 1990 - } \\
\text { Dec. } 2000(\mathrm{~N}=132)\end{array}$} \\
\hline Mean monthly change & $0.80 \%$ & $0.44 \%$ & $0.36 \%$ & $0.13 \%$ & $0.31 \%$ & $0.02 \%$ & $0.02 \%$ \\
\hline Standard Deviation & $3.58 \%$ & $0.11 \%$ & $3.55 \%$ & $0.90 \%$ & $2.01 \%$ & $0.45 \%$ & $1.76 \%$ \\
\hline Skewness & 1.39 & 0.22 & 1.37 & -1.01 & 0.83 & -0.31 & 0.78 \\
\hline Kurtosis & 3.15 & 0.06 & 3.07 & 1.98 & 1.63 & 2.03 & 2.76 \\
\hline \multicolumn{8}{|l|}{$\begin{array}{l}\text { Panel C. Jan. 2001 - } \\
\text { Dec. } 2006(\mathrm{~N}=72)\end{array}$} \\
\hline Mean monthly change & $0.30 \%$ & $0.22 \%$ & $0.08 \%$ & $0.21 \%$ & $0.05 \%$ & $0.06 \%$ & $-0.08 \%$ \\
\hline Standard Deviation & $1.76 \%$ & $0.13 \%$ & $1.78 \%$ & $0.51 \%$ & $1.57 \%$ & $0.21 \%$ & $1.11 \%$ \\
\hline Skewness & 1.12 & 0.57 & 1.17 & -0.19 & 0.65 & -0.20 & 0.77 \\
\hline Kurtosis & 1.53 & -1.06 & 1.57 & 0.31 & 0.09 & 1.40 & 1.84 \\
\hline
\end{tabular}

Barclay Currency Traders Index represents an equally-weighted average of managed programs that trade currency futures and/or cash forwards in the inter bank market. Source: The Barclay Group.

The risk-free return is the 1 -month LIBOR rate (less $12.5 \mathrm{bps)} \mathrm{quoted} \mathrm{at} \mathrm{the} \mathrm{end} \mathrm{of} \mathrm{month} t-1$ for the rate earned over month $t$. We used 1-month rates and not overnight rates since currency managers normally do not need 100\% liquidity. Source: British Bankers Association and Bloomberg.

Excess Returns are defined as the returns of the Barclay Currency Traders Index less risk-free returns.

The Beta1 G10 Carry Index reflects returns on a long high-yielding and short low-yielding strategy based on 10 countries and 17 currency pairs. Source: Citibank Investor Risk Advisory Group.

The AFX Index reflects returns on a trend following strategy involving three moving average rules applied to seven currency pairs, weighted by the volume of turnover in the spot market. Source: http://cwis.livjm.ac.uk/AFE/AFE_docs/AFX_Monthly.xls

The Beta1 G10 PPP Index reflects returns on 13 pairs of currencies selected from among the ten major currencies, taking long positions in currencies that are more than $20 \%$ undervalued against short positions in currencies that are more than $20 \%$ overvalued, using OECD measures of Purchasing Power Parity as a gauge for valuation. Source: Citibank Investor Risk Advisory Group.

The FX Volatility Index is a simple average of the 1-month implied volatility on EUR-USD options and USD-JPY options. Source: Citibank. 
Exhibit 3: Excess Currency Index Returns as a Function of Four Factors, Entire Sample

\begin{tabular}{|ccccccc|}
\hline & Intercept & Carry & $\begin{array}{c}\text { Trend } \\
\text { (AFX) }\end{array}$ & Value (PPP) & Volatility & $\mathbf{R}^{\mathbf{2}}$ \\
\hline 1) & -0.0009 & 0.7029 & 1.2817 & -1.0193 & 0.0421 & 0.6643 \\
t-value & -0.7376 & 3.3034 & 17.4451 & -2.2557 & 0.4371 & \\
\hline & & & & & & \\
\hline 2) & -0.0009 & 0.6922 & 1.2947 & -1.0702 & --- & 0.6640 \\
t-value & -0.7399 & 3.2815 & 19.3096 & -2.4559 & --- & \\
\hline 3) & 0.0020 & 0.3591 & --- & --- & --- & 0.0085 \\
t-value & 0.9282 & 1.3203 & --- & --- & --- & \\
\hline 4) & -0.0002 & --- & 1.3094 & --- & --- & 0.6456 \\
t-value & -0.1937 & --- & 19.1854 & --- & --- & \\
\hline 5) & 0.0027 & --- & --- & -0.5466 & --- & 0.0046 \\
t-value & 1.2860 & --- & --- & -0.9730 & --- & \\
\hline 6) & 0.0026 & & & --- & 0.6282 & 0.1031 \\
t-value & 1.3175 & & & --- & 4.8189 & \\
\hline
\end{tabular}

Summary of Regression Results for $R_{t}=\alpha+\sum_{i} \beta_{i} F_{i, t}+\varepsilon_{t}$

Full Sample, January 1990 - December 2006, 204 monthly observations

Barclay Currency Traders Index represents an equally-weighted average of managed programs that trade currency futures and/or cash forwards in the inter bank market. Source: The Barclay Group.

The Beta1 G10 Carry Index reflects returns on a long high-yielding and short low-yielding strategy based on 10 countries and 17 currency pairs. Source: Citibank Investor Risk Advisory Group.

The AFX Index reflects returns on a trend following strategy involving three moving average rules applied to seven currency pairs, weighted by the volume of turnover in the spot market. Source: http://cwis.livjm.ac.uk/AFE/AFE_docs/AFX_Monthly.xls

The Beta1 G10 PPP Index reflects returns on 13 pairs of currencies selected from among the ten major currencies, taking long positions in currencies that are more than $20 \%$ undervalued against short positions in currencies that are more than 20\% overvalued, using OECD measures of Purchasing Power Parity as a gauge for valuation. Source: Citibank Investor Risk Advisory Group.

The FX Volatility Index is a simple average of the 1-month implied volatility on EUR-USD options and USD-JPY options. Source: Citibank. 
Exhibit 4: Excess Currency Index Returns as a Function of Four Factors, Split Samples

Summary of Regression Results for $R_{t}=\alpha+\sum_{i} \beta_{i} F_{i, t}+\varepsilon_{t}$

Panel A. January 1990 - December 2000, 132 monthly observations

\begin{tabular}{|ccccccc|}
\hline & Intercept & Carry & $\begin{array}{c}\text { Trend } \\
\text { (AFX) }\end{array}$ & Value (PPP) & Volatility & $\mathbf{R}^{\mathbf{2}}$ \\
\hline 1) & -0.0016 & 0.7491 & 1.4490 & -1.3834 & -0.0478 & 0.6805 \\
t-value & -0.8824 & 2.7838 & 14.9170 & -2.4497 & -0.3881 & \\
\hline & & & & & & \\
\hline 2) & -0.0015 & 0.7590 & 1.4336 & -1.3190 & --- & 0.6801 \\
t-value & -0.8766 & 2.8432 & 16.2381 & -2.4517 & --- & \\
\hline 3) & 0.0032 & 0.2532 & --- & --- & --- & 0.0041 \\
t-value & 1.0377 & 0.7321 & --- & --- & --- & \\
\hline 4) & -0.0008 & --- & 1.4329 & --- & --- & 0.6586 \\
t-value & -0.4545 & --- & 15.8370 & --- & --- & \\
\hline 5) & 0.0036 & --- & --- & -0.4293 & --- & 0.0029 \\
t-value & 1.1708 & --- & --- & -0.6154 & --- & \\
\hline 6) & 0.0034 & & & --- & 0.6002 & 0.0878 \\
t-value & 1.1652 & & & -- & 3.5393 & \\
\hline
\end{tabular}

Panel B. January 2001 - December 2006, 72 monthly observations

\begin{tabular}{|ccccccc|}
\hline & Intercept & Carry & $\begin{array}{c}\text { Trend } \\
\text { (AFX) }\end{array}$ & Value (PPP) & Volatility & $\mathbf{R}^{\mathbf{2}}$ \\
\hline 1) & -0.0011 & 1.0367 & 0.7764 & -0.6420 & 0.3352 & 0.7673 \\
t-value & -1.0023 & 3.9942 & 9.7151 & -1.0105 & 3.0939 & \\
\hline & & & & & & \\
\hline 2) & -0.0010 & 0.8891 & 0.8785 & -0.7692 & --- & 0.7314 \\
t-value & -0.8694 & 3.2840 & 11.3712 & -1.1434 & --- & \\
\hline 3) & -0.0014 & 1.0256 & --- & --- & --- & 0.0875 \\
t-value & -0.6449 & 2.5911 & --- & --- & --- & \\
\hline 4) & 0.0003 & --- & 0.9390 & --- & --- & 0.6881 \\
t-value & 0.2606 & --- & 12.4279 & --- & --- & \\
\hline 5) & 0.0016 & --- & --- & -1.3202 & --- & 0.0248 \\
t-value & 0.7363 & --- & --- & -1.3369 & --- & \\
\hline 6) & 0.0013 & & & --- & 0.7461 & 0.2177 \\
t-value & 0.7054 & & & --- & 4.4137 & \\
\hline
\end{tabular}

Notes: See Exhibit 3. 
Exhibit 5: Performance of Individual Currency Managers

\begin{tabular}{|c|c|c|c|c|c|c|c|}
\hline Manager & $\begin{array}{c}\text { Average } \\
\text { Annual } \\
\text { Return }\end{array}$ & $\begin{array}{l}\text { Excess } \\
\text { Annual } \\
\text { Return }\end{array}$ & $\begin{array}{l}\text { Std. } \\
\text { Dev. }\end{array}$ & IR & $\begin{array}{c}\text { Annual } \\
\text { Alpha }\end{array}$ & $\begin{array}{l}\text { Tracking } \\
\text { Error }\end{array}$ & $\mathrm{IR}^{*}$ \\
\hline M1 & $22.0 \%$ & $19.34 \%$ & $14.71 \%$ & 1.31 & 22.13 & 14.57 & 1.52 \\
\hline M2 & $6.4 \%$ & $3.70 \%$ & $8.62 \%$ & 0.74 & $-2.48 \%$ & $4.81 \%$ & -0.52 \\
\hline M3 & $2.5 \%$ & $-0.16 \%$ & $3.00 \%$ & -0.05 & $0.31 \%$ & $2.94 \%$ & 0.11 \\
\hline M4 & $5.7 \%$ & $2.98 \%$ & $5.16 \%$ & 0.58 & $2.91 \%$ & $4.68 \%$ & 0.62 \\
\hline M5 & $5.4 \%$ & $2.73 \%$ & $8.00 \%$ & 0.36 & $-4.19 \%$ & $6.24 \%$ & -0.67 \\
\hline M6 & $10.7 \%$ & $8.00 \%$ & $22.51 \%$ & 0.36 & $-8.97 \%$ & $15.75 \%$ & -0.57 \\
\hline M7 & $4.0 \%$ & $1.35 \%$ & $1.31 \%$ & 1.03 & $1.91 \%$ & $1.20 \%$ & 1.60 \\
\hline M8 & $7.2 \%$ & $4.53 \%$ & $3.77 \%$ & 1.20 & $6.16 \%$ & $3.44 \%$ & 1.79 \\
\hline M9 & $14.5 \%$ & $11.80 \%$ & $15.32 \%$ & 0.77 & $10.43 \%$ & $15.27 \%$ & 0.68 \\
\hline M10 & $6.5 \%$ & $3.78 \%$ & $6.96 \%$ & 0.54 & $3.08 \%$ & $6.94 \%$ & 0.44 \\
\hline M11 & $0.8 \%$ & $-1.87 \%$ & $0.94 \%$ & -1.99 & $-1.86 \%$ & $0.92 \%$ & -2.03 \\
\hline M12 & $1.4 \%$ & $-1.26 \%$ & $12.15 \%$ & -0.10 & $0.57 \%$ & $11.26 \%$ & 0.05 \\
\hline M13 & $2.3 \%$ & $-0.37 \%$ & $13.83 \%$ & -0.03 & $0.22 \%$ & $10.20 \%$ & 0.02 \\
\hline M14 & $8.1 \%$ & $5.42 \%$ & $29.34 \%$ & 0.18 & $13.08 \%$ & $27.09 \%$ & 0.48 \\
\hline M15 & $5.9 \%$ & $3.18 \%$ & $11.92 \%$ & 0.27 & $-0.26 \%$ & $9.63 \%$ & -0.03 \\
\hline M16 & $7.7 \%$ & $5.04 \%$ & $6.39 \%$ & 0.79 & $2.67 \%$ & $5.90 \%$ & 0.45 \\
\hline M17 & $7.1 \%$ & $4.43 \%$ & $13.73 \%$ & 0.32 & $-7.39 \%$ & $11.09 \%$ & -0.67 \\
\hline M18 & $2.2 \%$ & $-0.49 \%$ & $4.03 \%$ & -0.12 & $-2.21 \%$ & $3.76 \%$ & -0.59 \\
\hline M19 & $5.0 \%$ & $2.27 \%$ & $8.04 \%$ & 0.28 & $2.84 \%$ & $7.84 \%$ & 0.36 \\
\hline M20 & $6.2 \%$ & $3.52 \%$ & $39.21 \%$ & 0.09 & $3.27 \%$ & $23.87 \%$ & 0.14 \\
\hline M21 & $5.9 \%$ & $3.24 \%$ & $23.98 \%$ & 0.13 & $-5.01 \%$ & $15.87 \%$ & -0.32 \\
\hline M22 & $8.0 \%$ & $5.31 \%$ & $8.88 \%$ & 0.60 & $-0.54 \%$ & $7.68 \%$ & -0.07 \\
\hline M23 & $9.9 \%$ & $7.24 \%$ & $11.57 \%$ & 0.63 & 7.71\% & $11.04 \%$ & 0.70 \\
\hline M24 & $2.7 \%$ & $-0.02 \%$ & $6.56 \%$ & 0.00 & $0.22 \%$ & $3.92 \%$ & 0.06 \\
\hline M25 & $17.6 \%$ & $14.90 \%$ & $8.91 \%$ & 1.67 & $12.73 \%$ & $8.34 \%$ & 1.53 \\
\hline M26 & $25.7 \%$ & $22.98 \%$ & $14.82 \%$ & 1.55 & $25.99 \%$ & $14.28 \%$ & 1.82 \\
\hline M27 & $2.7 \%$ & $-0.04 \%$ & $5.89 \%$ & -0.01 & $-0.42 \%$ & $4.34 \%$ & -0.10 \\
\hline M28 & $5.7 \%$ & $3.02 \%$ & $3.86 \%$ & 0.78 & $3.51 \%$ & $3.79 \%$ & 0.93 \\
\hline M29 & $22.7 \%$ & $19.97 \%$ & $12.74 \%$ & 1.57 & $19.53 \%$ & $12.14 \%$ & 1.61 \\
\hline M30 & $10.0 \%$ & $7.27 \%$ & $22.39 \%$ & 0.32 & $3.32 \%$ & $14.42 \%$ & 0.23 \\
\hline M31 & $3.7 \%$ & $1.02 \%$ & $13.90 \%$ & 0.07 & $-1.71 \%$ & $8.18 \%$ & -0.21 \\
\hline M32 & $10.3 \%$ & $7.62 \%$ & $13.71 \%$ & 0.56 & $8.50 \%$ & $9.07 \%$ & 0.94 \\
\hline M33 & $14.7 \%$ & $11.98 \%$ & $19.49 \%$ & 0.61 & $12.72 \%$ & $18.29 \%$ & 0.70 \\
\hline M34 & $5.7 \%$ & $2.98 \%$ & $3.47 \%$ & 0.86 & $1.72 \%$ & $2.99 \%$ & 0.57 \\
\hline Average & $8.14 \%$ & $5.45 \%$ & & 0.47 & $3.84 \%$ & & 0.34 \\
\hline Maximum & $25.70 \%$ & $22.98 \%$ & & 1.67 & $25.99 \%$ & & 1.81 \\
\hline Median & $6.30 \%$ & $6.30 \%$ & & 0.45 & $2.29 \%$ & & 0.29 \\
\hline Minimum & $0.80 \%$ & $0.80 \%$ & & -1.99 & $-8.97 \%$ & & -2.02 \\
\hline
\end{tabular}

Notes: Based on 72 monthly observations, January 2001 - December 2006. 


\section{Exhibit 5: Performance of Individual Currency Managers - Continued}

Average annual return is the total return earned by the fund.

Excess annual return is the total return earned by the fund minus the risk-free rate, which we proxy as the 1-month USD LIBID rate.

IR is an information ratio, equal to the ratio of average annual excess returns to the standard deviation of the excess returns.

Annual alpha is the annualized alpha coefficient estimated for equation 1 for each manager.

Tracking error is the standard deviation of annualized alpha returns.

IR* is an alternative information ratio, equal to the ratio of average alpha returns, $\alpha_{j}$ as defined in our framework in equation (1), to the tracking error (the standard deviation of the alpha returns, $\left.\sigma\left(\alpha_{\mathrm{j}}\right)\right)$. 
Exhibit 6: Regression Results for Individual Currency Managers

Regression Results for $R_{j, t}=\alpha_{j}+\sum_{i} \beta_{i, j} F_{i, t}+\varepsilon_{j, t}$ for managers $\mathrm{j}=1, \ldots 34$.

Based on 72 monthly observations, January 2001 - December 2006.

\begin{tabular}{|c|c|c|c|c|c|c|c|c|c|c|c|}
\hline Manager & Intercept & T-Stat & $\begin{array}{l}\text { Beta } \\
\text { Carry }\end{array}$ & T-Stat & $\begin{array}{l}\text { Beta } \\
\text { Trend }\end{array}$ & T-Stat & $\begin{array}{l}\text { Beta } \\
\text { Value }\end{array}$ & T-Stat & $\begin{array}{c}\text { Beta } \\
\text { Volatility }\end{array}$ & T-Stat & $\begin{array}{c}\mathrm{R}- \\
\text { Square }\end{array}$ \\
\hline M1 & 0.0184 & 3.3236 & -0.6550 & -0.5143 & -0.0269 & -0.0687 & -1.6564 & -0.5314 & -0.1815 & -0.3414 & 0.0189 \\
\hline $\mathrm{M} 2$ & -0.0020 & -1.1294 & 2.2714 & 5.4067 & 0.9036 & 6.9854 & 0.3357 & 0.3265 & 0.3762 & 2.1457 & 0.6889 \\
\hline M3 & 0.0002 & 0.2317 & -0.3562 & -1.3858 & -0.0029 & -0.0370 & 0.6393 & 1.0164 & 0.0662 & 0.6172 & 0.0401 \\
\hline M4 & 0.0024 & 1.3573 & -0.4595 & -1.1223 & -0.2625 & -2.0827 & 2.1998 & 2.1954 & 0.3418 & 2.0002 & 0.1757 \\
\hline M5 & -0.0034 & -1.4687 & 2.6656 & 4.8841 & 0.7108 & 4.2298 & -0.2206 & -0.1651 & 0.0630 & 0.2768 & 0.5157 \\
\hline M6 & -0.0074 & -1.2462 & 6.6620 & 4.8397 & 1.7715 & 4.1797 & -0.8883 & -0.2636 & 0.2216 & 0.3857 & 0.5103 \\
\hline M7 & 0.0015 & 3.4981 & -0.1508 & -1.4402 & 0.0155 & 0.4808 & -0.1610 & -0.6284 & 0.0763 & 1.7460 & 0.1658 \\
\hline M8 & 0.0051 & 3.9239 & -0.4723 & -1.5731 & 0.0579 & 0.6264 & -0.3537 & -0.4812 & 0.2144 & 1.7106 & 0.1681 \\
\hline M9 & 0.0086 & 1.4950 & 0.1918 & 0.1436 & 0.0280 & 0.0681 & 1.3053 & 0.3995 & 0.1539 & 0.2761 & 0.0058 \\
\hline M10 & 0.0025 & 0.9721 & 0.0786 & 0.1297 & 0.0439 & 0.2355 & 0.6464 & 0.4356 & 0.0295 & 0.1167 & 0.0066 \\
\hline M11 & -0.0015 & -4.4319 & -0.0810 & -1.0098 & -0.0138 & -0.5622 & 0.2719 & 1.3853 & 0.0107 & 0.3205 & 0.0479 \\
\hline M12 & 0.0004 & 0.1100 & -1.2423 & -1.2625 & 0.5025 & 1.6586 & 2.1556 & 0.8951 & 0.7023 & 1.7099 & 0.1410 \\
\hline M13 & 0.0001 & 0.0482 & 0.1051 & 0.1180 & 1.4515 & 5.2885 & -1.5816 & -0.7250 & 0.5213 & 1.4012 & 0.4566 \\
\hline M14 & 0.0109 & 1.0571 & -4.0068 & -1.6923 & 2.1114 & 2.8963 & -0.3642 & -0.0628 & -1.6972 & -1.7174 & 0.1479 \\
\hline M15 & -0.0002 & -0.0582 & 1.9720 & 2.3417 & 0.9330 & 3.5983 & -2.3471 & -1.1387 & 0.3023 & 0.8600 & 0.3462 \\
\hline M16 & 0.0022 & 0.9892 & -0.1483 & -0.2876 & 0.2014 & 1.2678 & 3.5933 & 2.8459 & 0.1525 & 0.7083 & 0.1461 \\
\hline M17 & -0.0061 & -1.4582 & 3.2239 & 3.3270 & 0.1397 & 0.4685 & 4.8788 & 2.0572 & 0.1974 & 0.4882 & 0.3483 \\
\hline M18 & -0.0018 & -1.2855 & 0.3595 & 1.0952 & -0.0601 & -0.5954 & 1.3643 & 1.6981 & 0.2302 & 1.6802 & 0.1313 \\
\hline M19 & 0.0023 & 0.7936 & 0.5512 & 0.8039 & -0.3075 & -1.4568 & -1.9338 & -1.1523 & 0.3323 & 1.1612 & 0.0474 \\
\hline M20 & 0.0027 & 0.2994 & -0.7516 & -0.3602 & 5.5147 & 8.5848 & -0.5740 & -0.1124 & 0.6160 & 0.7074 & 0.6294 \\
\hline M21 & -0.0041 & -0.6902 & 2.5661 & 1.8694 & 3.0227 & 7.0749 & 0.4007 & 0.1180 & 0.3109 & 0.5369 & 0.5618 \\
\hline M22 & -0.0004 & -0.1536 & 1.5987 & 2.3802 & 0.3345 & 1.6175 & 2.3903 & 1.4541 & 0.2561 & 0.9135 & 0.2505 \\
\hline M23 & 0.0064 & 1.5299 & -0.4939 & -0.5120 & 0.3493 & 1.1761 & 1.4823 & 0.6278 & 0.6301 & 1.5648 & 0.0906 \\
\hline
\end{tabular}




\begin{tabular}{|c|c|c|c|c|c|c|c|c|c|c|c|}
\hline M24 & 0.0001 & 0.1236 & -0.5023 & -1.4654 & 0.9771 & 9.2566 & 0.6966 & 0.8302 & 0.0747 & 0.5223 & 0.6429 \\
\hline M25 & 0.0106 & 3.3421 & -0.0430 & -0.0590 & 0.1080 & 0.4816 & 3.6282 & 2.0347 & 0.6363 & 2.0924 & 0.1244 \\
\hline M26 & 0.0216 & 3.9814 & -1.4220 & -1.1389 & 0.1577 & 0.4102 & 1.5233 & 0.4985 & 0.7424 & 1.4245 & 0.0705 \\
\hline M27 & -0.0003 & -0.2091 & 0.2896 & 0.7629 & 0.4485 & 3.8373 & -0.1075 & -0.1157 & 0.5799 & 3.6603 & 0.4567 \\
\hline M28 & 0.0029 & 2.0267 & -0.0783 & -0.2363 & -0.0064 & -0.0633 & -0.1904 & -0.2346 & 0.1627 & 1.1755 & 0.0347 \\
\hline M29 & 0.0162 & 3.5206 & -1.0116 & -0.9535 & 0.0415 & 0.1271 & 4.8410 & 1.8645 & 0.8304 & 1.8753 & 0.0919 \\
\hline M30 & 0.0027 & 0.5040 & 4.0590 & 3.2210 & 2.0985 & 5.4085 & -8.4047 & -2.7251 & 1.1319 & 2.1520 & 0.5855 \\
\hline M31 & -0.0014 & -0.4590 & 1.5484 & 2.1666 & 1.7395 & 7.9050 & -2.2846 & -1.3061 & 0.4585 & 1.5370 & 0.6541 \\
\hline M32 & 0.0070 & 2.0515 & -0.2912 & -0.3673 & 1.5875 & 6.5019 & -0.5135 & -0.2645 & 0.7304 & 2.2068 & 0.5621 \\
\hline M33 & 0.0106 & 1.5220 & 1.0493 & 0.6563 & -0.3504 & -0.7118 & -1.9321 & -0.4938 & 1.8784 & 2.8150 & 0.1196 \\
\hline M34 & 0.0014 & 1.2557 & 0.5082 & 1.9439 & 0.2158 & 2.6814 & -0.0213 & -0.0333 & 0.1457 & 1.3351 & 0.2583 \\
\hline $\begin{array}{l}\text { "Fund of } \\
\text { funds" }\end{array}$ & 0.0031 & 2.9295 & 0.5157 & 2.0574 & 0.7187 & 9.3120 & 0.2593 & 0.4227 & 0.3323 & 3.1762 & 0.7285 \\
\hline Average & 0.0032 & 0.7461 & 0.5157 & 0.6091 & 0.7187 & 2.3961 & 0.2594 & 0.3014 & 0.3323 & 1.1784 & 0.2718 \\
\hline Maximum & 0.0216 & 3.9814 & 6.6620 & 5.4067 & 5.5147 & 9.2566 & 4.8788 & 2.8459 & 1.8784 & 3.6603 & 0.6889 \\
\hline Median & 0.0019 & 0.6488 & 0.0178 & 0.0295 & 0.2086 & 1.2220 & 0.1253 & 0.0424 & 0.2792 & 1.2553 & 0.1670 \\
\hline Minimum & -0.0074 & -4.4319 & -4.0068 & -1.6923 & -0.3504 & -2.0827 & -8.4047 & -2.7251 & -1.6972 & -1.7174 & 0.0058 \\
\hline
\end{tabular}




\section{Exhibit 7: $\quad$ Market Timing Model}

Regression Results for $R_{j, t}=\alpha_{j}+\sum_{i} \beta_{i, j} F_{i, t}+\sum_{i} \gamma_{i, j} F_{i, t}^{2}+\mu_{j, t}$ for managers $\mathrm{j}=1, \ldots 34$.

Based on 72 monthly observations, January 2001 - December 2006.

\begin{tabular}{|c|c|c|c|c|c|c|c|c|c|c|c|c|c|c|c|c|c|c|c|}
\hline & $\begin{array}{l}\text { Inter- } \\
\text { cept }\end{array}$ & T-St. & $\begin{array}{c}\beta \\
\text { Carry }\end{array}$ & T-St. & $\begin{array}{c}\boldsymbol{\beta} \\
\text { Trend }\end{array}$ & T-St. & $\begin{array}{c}\boldsymbol{\beta} \\
\text { Value }\end{array}$ & T-St. & $\begin{array}{c}\beta \\
\text { Vol. }\end{array}$ & T-St. & $\begin{array}{c}\gamma \\
\text { Carry }\end{array}$ & T-St. & $\begin{array}{c}\gamma \\
\text { Trend }\end{array}$ & T-St. & $\begin{array}{c}\gamma \\
\text { Value }\end{array}$ & T-St. & $\begin{array}{c}\gamma \\
\text { Vol. }\end{array}$ & T-St. & R2 \\
\hline M1 & 0.0144 & 1.82 & -1.88 & -1.91 & 0.07 & 0.14 & -1.02 & -0.32 & -0.38 & -0.65 & 304.65 & 2.08 & 1.31 & 0.07 & -324.07 & -0.50 & -16.19 & -0.67 & 0.08 \\
\hline M2 & -0.0017 & -0.63 & 1.95 & 4.13 & 0.96 & 6.78 & 0.58 & 0.54 & 0.37 & 1.93 & 72.74 & 1.38 & -1.49 & -0.25 & -77.12 & -0.31 & -10.28 & $\begin{array}{l}-1.28 \\
\end{array}$ & 0.70 \\
\hline M3 & 0.0006 & 0.39 & -0.38 & -1.37 & 0.04 & 0.57 & 0.62 & 0.99 & 0.06 & 0.57 & -0.24 & -0.00 & -7.54 & -2.15 & 59.79 & 0.41 & 9.74 & 2.04 & 0.15 \\
\hline M4 & 0.0007 & 0.25 & -0.58 & -1.23 & -0.27 & -1.93 & 2.14 & 2.01 & 0.28 & 1.44 & 36.08 & 0.69 & 0.81 & 0.13 & 17.77 & 0.07 & 4.61 & 0.57 & 0.18 \\
\hline M5 & -0.0010 & -0.26 & 2.89 & 4.65 & 0.78 & 4.20 & -0.38 & -0.27 & 0.23 & 0.91 & -58.85 & -0.85 & -6.43 & -0.83 & 341.23 & 1.07 & -8.75 & -0.82 & 0.53 \\
\hline M6 & -0.0011 & -0.12 & 7.03 & 4.48 & 1.96 & 4.18 & -1.09 & -0.31 & 0.61 & 0.95 & -106.5 & -0.61 & -16.66 & -0.85 & 710.23 & 0.88 & -23.74 & -0.89 & 0.52 \\
\hline M7 & 0.0012 & 1.74 & -0.11 & -0.96 & 0.01 & 0.43 & -0.26 & -0.98 & 0.08 & 1.74 & -5.02 & -0.38 & -0.34 & -0.23 & 97.03 & 1.59 & 0.89 & 0.44 & 0.20 \\
\hline M8 & 0.0045 & 2.19 & -0.33 & -0.98 & 0.06 & 0.58 & -0.63 & -0.83 & 0.25 & 1.80 & -23.58 & -0.62 & -1.22 & -0.28 & 278.46 & 1.59 & 1.81 & 0.31 & 0.20 \\
\hline M9 & 0.0025 & 0.31 & 0.86 & 0.60 & -0.23 & -0.59 & 0.44 & 0.08 & -0.10 & -0.16 & -132.7 & -0.84 & 10.73 & 0.67 & 59.35 & 0.04 & 51.63 & 2.37 & 0.09 \\
\hline M10 & -0.0005 & -0.14 & 0.33 & 0.53 & -0.07 & -0.39 & 0.27 & 0.12 & -0.11 & -0.40 & -48.61 & -0.71 & 3.90 & 0.50 & -5.64 & -0.01 & 27.22 & 2.61 & 0.10 \\
\hline M11 & -0.0020 & -4.16 & -0.09 & -1.73 & -0.01 & -0.97 & 0.23 & 1.86 & -0.00 & -0.24 & 5.94 & 0.36 & -0.50 & -0.34 & 20.07 & 0.49 & 3.38 & 2.39 & 0.13 \\
\hline M12 & -0.0058 & -0.85 & -1.31 & -1.16 & 0.40 & 1.20 & 1.59 & 0.62 & 0.54 & 1.17 & 54.30 & 0.43 & 7.57 & 0.53 & 304.72 & 0.52 & 14.24 & 0.74 & 0.16 \\
\hline M13 & -0.0008 & -0.14 & 0.07 & 0.07 & 1.52 & 4.99 & -1.93 & -0.84 & 0.57 & 1.37 & 17.08 & 0.15 & -7.92 & -0.62 & 476.21 & 0.91 & 3.65 & 0.21 & 0.47 \\
\hline M14 & 0.0108 & 0.64 & -2.25 & -0.97 & 1.47 & 2.50 & -0.71 & -0.16 & -1.79 & -1.45 & -397.0 & -0.71 & 55.25 & 2.40 & -911.11 & -0.92 & -1.61 & -0.05 & 0.25 \\
\hline M15 & -0.0094 & -2.18 & 1.60 & 2.52 & 0.92 & 3.23 & -3.24 & -1.22 & 0.12 & 0.30 & 139.36 & 2.11 & -1.56 & -0.16 & 775.14 & 0.95 & 22.84 & 1.27 & 0.44 \\
\hline M16 & 0.0004 & 0.11 & -0.37 & -0.64 & 0.21 & 1.24 & 3.56 & 2.67 & 0.09 & 0.38 & 62.25 & 0.95 & -1.10 & -0.14 & 54.97 & 0.18 & 2.94 & 0.29 & 0.16 \\
\hline M17 & -0.0090 & -1.36 & 2.84 & 2.59 & 0.18 & 0.57 & 4.87 & 1.97 & 0.03 & 0.07 & 89.84 & 0.73 & -9.11 & -0.66 & -25.70 & -0.04 & 25.69 & 1.37 & 0.37 \\
\hline M18 & -0.0064 & -3.04 & 0.08 & 0.22 & -0.12 & -1.16 & 1.18 & 1.48 & 0.09 & 0.65 & 92.97 & 2.37 & 8.49 & 1.92 & 62.18 & 0.34 & 0.56 & 0.09 & 0.25 \\
\hline M19 & -0.0011 & -0.24 & 0.21 & 0.27 & -0.38 & -1.66 & -1.82 & -1.03 & 0.18 & 0.57 & 98.34 & 1.13 & 12.25 & 1.25 & -226.41 & -0.56 & -6.35 & -0.47 & 0.08 \\
\hline M20 & -0.0210 & -1.55 & 0.49 & 0.21 & 4.75 & 7.06 & -3.70 & -0.73 & 0.29 & 0.31 & -104.7 & -0.42 & 72.88 & 2.59 & 1602.9 & 1.39 & 7.39 & 0.19 & 0.68 \\
\hline M21 & -0.0117 & -1.29 & 2.32 & 1.55 & 2.96 & 6.31 & -0.42 & -0.11 & 0.29 & 0.43 & 120.85 & 0.48 & 13.18 & 0.58 & 822.99 & 1.01 & \begin{tabular}{|l|}
-18.4 \\
\end{tabular} & -0.67 & 0.58 \\
\hline M22 & 0.0022 & 0.49 & 2.12 & 2.78 & 0.30 & 1.31 & 2.12 & 1.29 & 0.39 & 1.26 & -129.7 & -1.53 & 1.76 & 0.18 & 131.35 & 0.33 & -5.79 & -0.44 & 0.28 \\
\hline
\end{tabular}




\begin{tabular}{|c|c|c|c|c|c|c|c|c|c|c|c|c|c|c|c|c|c|c|c|}
\hline M23 & -0.0017 & -0.27 & -1.16 & -1.11 & 0.07 & 0.22 & 1.99 & 0.84 & 0.10 & 0.25 & 185.10 & 1.60 & 29.50 & 2.26 & -1108.05 & -2.07 & 13.00 & 0.73 & 0.21 \\
\hline M24 & -0.0043 & -2.05 & -0.59 & -2.15 & 0.85 & 7.56 & 0.49 & 0.71 & -0.08 & -0.47 & 48.59 & 1.11 & 12.09 & 3.08 & -52.80 & -0.31 & 5.21 & 1.00 & 0.68 \\
\hline M25 & 0.0006 & 0.14 & 0.11 & 0.14 & -0.07 & -0.32 & 2.39 & 1.36 & 0.51 & 1.60 & 37.24 & 0.43 & 18.34 & 1.88 & 852.38 & 2.13 & 5.30 & 0.39 & 0.25 \\
\hline M26 & 0.0114 & 1.36 & -1.01 & -0.72 & -0.11 & -0.26 & 0.35 & 0.11 & 0.43 & 0.75 & -42.71 & -0.27 & 14.42 & 0.83 & 383.00 & 0.54 & 48.48 & 2.05 & 0.14 \\
\hline M27 & -0.0062 & -2.68 & 0.32 & 1.30 & 0.23 & 2.47 & -0.44 & -0.55 & 0.39 & 2.63 & 28.79 & 0.55 & 21.70 & 3.95 & -83.24 & -0.47 & 1.77 & 0.25 & 0.59 \\
\hline M28 & -0.0018 & -0.90 & 0.00 & 0.01 & -0.07 & -0.72 & -0.84 & -1.08 & 0.11 & 0.77 & 15.68 & 0.40 & 5.92 & 1.36 & 489.63 & 2.75 & 6.24 & 1.05 & 0.21 \\
\hline M29 & 0.0189 & 2.62 & -0.04 & -0.03 & 0.03 & 0.09 & 4.05 & 1.50 & 1.05 & 2.13 & -232.2 & -1.74 & -8.30 & -0.55 & 680.58 & 1.11 & 14.05 & 0.68 & 0.14 \\
\hline M30 & -0.0132 & -1.60 & 3.67 & 2.67 & 1.67 & 4.06 & -9.00 & -2.91 & 0.49 & 0.87 & 170.98 & 1.12 & 39.80 & 2.32 & -389.84 & -0.55 & 32.09 & 1.37 & 0.63 \\
\hline M31 & -0.0090 & -1.89 & 1.07 & 1.34 & 1.64 & 6.91 & -2.57 & -1.43 & 0.21 & 0.64 & 152.12 & 1.72 & 10.60 & 1.06 & 79.38 & 0.19 & 8.89 & 0.65 & 0.68 \\
\hline M32 & -0.0026 & -0.50 & -0.12 & -0.14 & 1.34 & 5.19 & -1.44 & -0.73 & 0.44 & 1.25 & 16.48 & 0.17 & 17.59 & 1.62 & 303.13 & 0.68 & 29.64 & 2.01 & 0.61 \\
\hline M33 & 0.0079 & 0.71 & 1.81 & 0.98 & -0.49 & -0.89 & -2.92 & -0.70 & 1.95 & 2.57 & -148.1 & -0.72 & 9.27 & 0.40 & 666.94 & 0.70 & 6.72 & 0.21 & 0.13 \\
\hline M34 & -0.0010 & -0.60 & 0.42 & 1.42 & 0.16 & 1.91 & -0.16 & -0.24 & 0.07 & 0.65 & 36.51 & 1.11 & 5.56 & 1.51 & 53.44 & 0.35 & 0.24 & 0.04 & 0.30 \\
\hline "FoF" & -0.0010 & -0.66 & 0.58 & 2.24 & 0.61 & 7.82 & -0.16 & -0.28 & 0.23 & 2.14 & 10.46 & 0.36 & 9.14 & 2.79 & 179.96 & 1.34 & 7.56 & 1.69 & 0.78 \\
\hline Aver. & -0.0010 & -0.40 & 0.59 & 0.51 & 0.61 & 1.91 & -0.17 & 0.11 & 0.23 & 0.78 & 10.47 & 0.34 & 9.14 & 0.71 & 179.97 & 0.43 & 7.56 & 0.59 & 0.33 \\
\hline Max. & 0.0189 & 2.62 & 7.03 & 4.65 & 4.75 & 7.56 & 4.87 & 2.67 & 1.95 & 2.63 & 304.65 & 2.37 & 72.88 & 3.95 & 1602.90 & 2.75 & 51.63 & 2.61 & 0.70 \\
\hline Med. & -0.0011 & -0.25 & 0.10 & 0.18 & 0.17 & 0.89 & -0.21 & -0.14 & 0.22 & 0.70 & 22.94 & 0.42 & 5.74 & 0.52 & 70.78 & 0.38 & 4.91 & 0.42 & 0.25 \\
\hline Min. & -0.0210 & -4.16 & -2.25 & -2.15 & -0.49 & -1.93 & -9.00 & -2.91 & -1.79 & -1.45 & -397.0 & -1.74 & -16.66 & -2.15 & -1108.0 & -2.07 & -23.74 & -1.28 & 0.08 \\
\hline
\end{tabular}

Results for the BCTI index, full sample - 1990-2006

\begin{tabular}{|c|c|c|c|c|c|c|c|c|c|c|c|c|c|c|c|c|c|c|c|}
\hline BCTI & -0.0023 & -1.45 & 0.80 & 3.68 & 1.17 & 14.28 & -1.18 & -2.65 & 0.02 & 0.27 & 12.55 & 0.87 & 7.77 & 3.34 & -89.72 & -1.61 & -3.13 & -1.12 & 0.68 \\
\hline
\end{tabular}


Exhibit 8: The Relationship Between Currency Managers' Alpha and $\mathbf{R}^{2}$

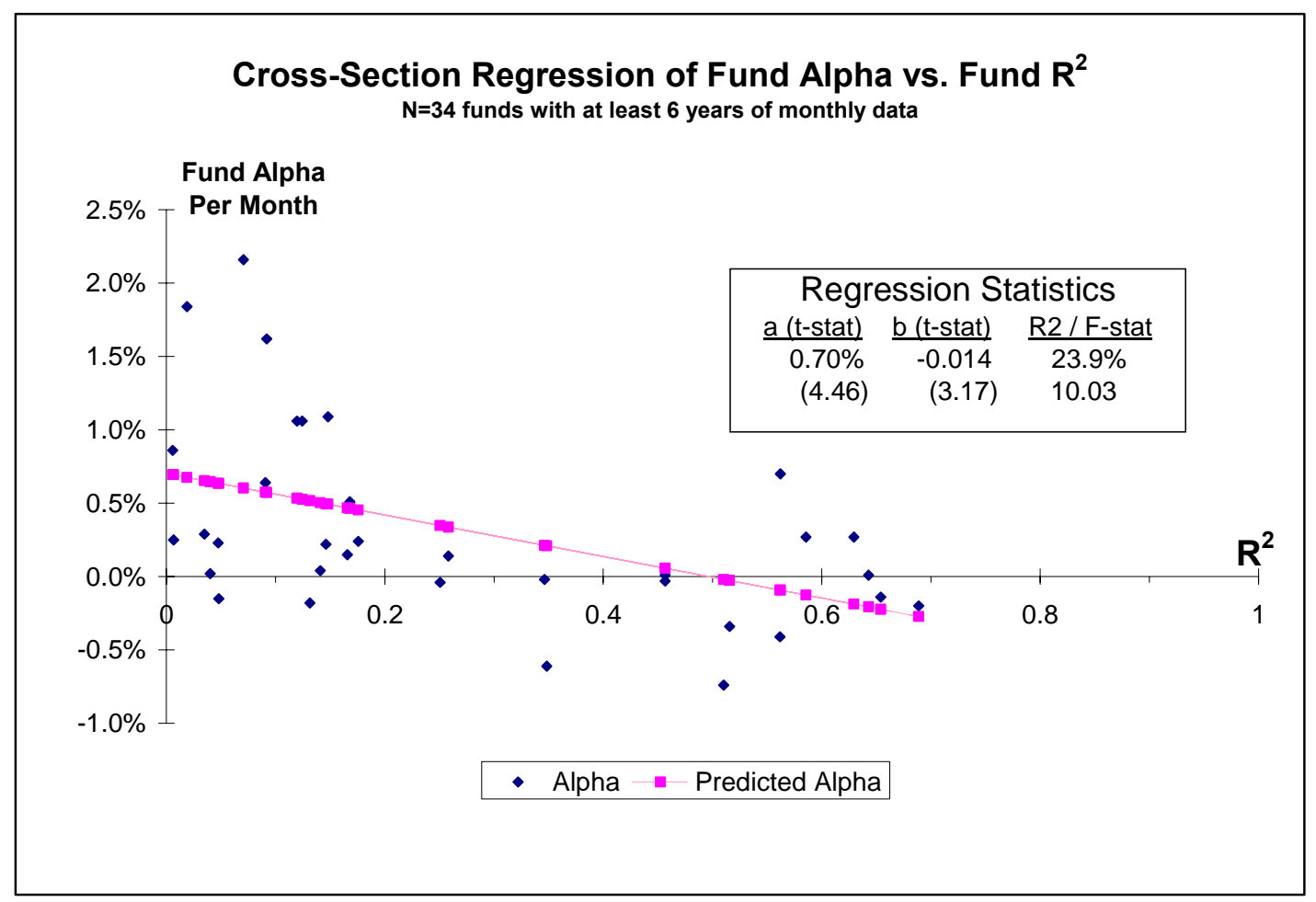

